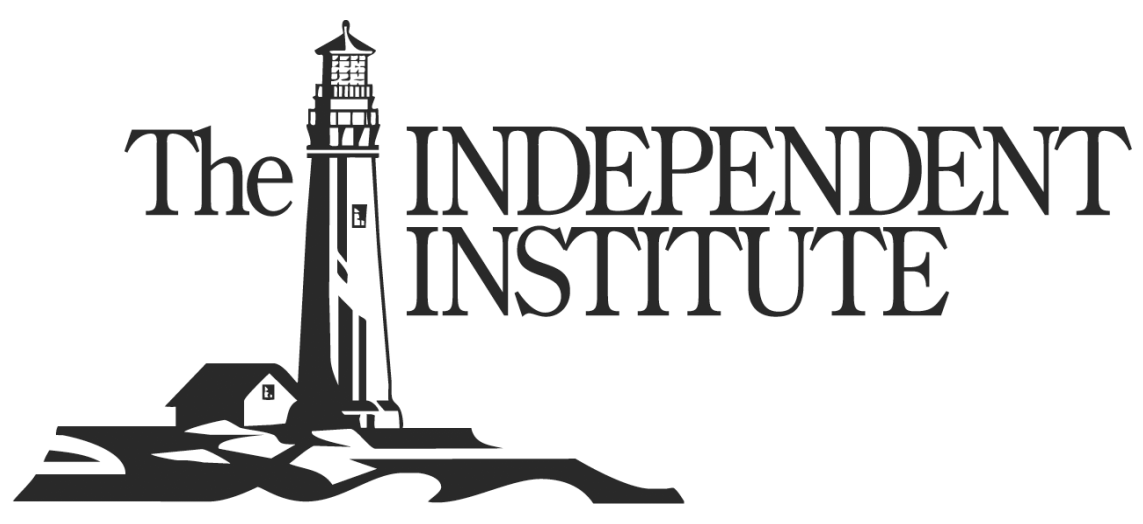

\title{
Economic Principles of Constitutions: An Economic Analysis of Constitutional Law
}

\section{Prof. Dr.J ürgen G. Backhaus}

I ndependent I nstitute Working Paper Number 40

August 2001 


\title{
Economic Principles of Constitutions/
}

\section{An Economic Analysis of Constitutional Law}

\author{
Prof. Dr. Jürgen G. Backhaus \\ Krupp Chair in \\ Public Finance and Fiscal Sociology \\ University of Erfurt \\ P.O. Box 900221 \\ 99105 Erfurt \\ Germany \\ tel: +49-361-737 4551 \\ fax: +49-361-737 4559 \\ email: juergen.backhaus@uni-erfurt.de
}

\begin{abstract}
Perhaps, the 1990's will be the decade of constitution writing. With many European States gaining their independence or reshaping their contours, new constitutions will be drawn up. Recent advances in the economic analysis of law can help to make this difficult task more feasible. This essay starts by giving an introduction into the economic analysis of constitutional law. Part I contains an analysis of constitutional guarantees of basic (individual) rights and procedures, illustrated with three constitutions, the American constitution of 1789 as amended in 1792, the German Basic Law of 1949 and the Dutch Basic Law of 1983. Although constitutions are meant to be permanent, they continuously change without amendment. Part II offers an analysis of constitutional change without amendment. Whoever wants to draft a constitution needs to know how the basic guarantees work, how procedural rules interconnect basic guarantees and decision takers, and what chances there are that the meaning of a constitutional provision can be turned upside down. Economic analysis of constitutions speaks to these three problems.
\end{abstract}




\section{Introduction}

The economic analysis of constitutional issues does not figure quite as prominently in the modern law and economics literature as some other issues do, such as tort and liability issues. One could be tempted to conclude that law and economics scholarship is silent on constitutional issues. Nothing could be further from the truth, hence the purpose of this essay to provide an overview and an interpretation of some main lines of development.

Generally speaking, the economic analysis of law can consist in three fairly different analytical endeavours. The three different approaches can either be entertained separately, or they can be combined. The first approach, the predictive analysis, tries to answer the question: what are the likely consequences of a particular legal rule? The answer will involve a set of predictions, which, in principle, should be testable and refutable. The second approach, the functional interpretation, tries to answer the question: why has a particular legal arrangement taken the form we can observe? The purpose of this analysis is to uncover the many considerations (concerning costs and benefits) which enter into particular legal arrangements as they develop over time. This type of analysis is extremely important in terms of legal policy. With a stroke of the pen, large costs can be imposed on unsuspecting parties if existing legal arrangements are changed without due regard to the purposes they fulfill. Again, the result of this type of analysis can (and should) take the form of a testable hypothesis which is, in principle, refutable. The third type of analysis, the "normative" analysis, involves the norms embodied in legal rules. Here, the economist can assist in two ways. On the one hand, economic analysis can help in uncovering the relationship between particular norms. Secondly, the analysis can show to what extent there are trade-offs between different norms, such as trade-offs between liberty and equality, and how they can best be resolved. "Best" refers to a criterion which the economist cannot provide. The "normative" analysis is not normative in the sense that it derives value judgements; it is only normative in the sense that it deals with the relationships between norms. Again, this analysis can yield conclusions, which are refutable. However, refutation in this case is by logic and not by empirical analysis. ${ }^{1}$

An additional complication not encountered generally arises in the economic analysis of constitutional issues because the constitution itself determines the scope and structure of those legal issues that are normally subject to economic analysis. Although a constitution, as compared to other legal documents, is more immutable, constitutions are also subject to substantial change. The change, however, is subtle and not always easy to detect, further complicating the analytical problem. Although a constitution must be considered the basic document on which a society can be said to have agreed to live and by which it wants to arrange and settle its affairs, ${ }^{2}$ constitutional norms are not by virtue of this reasoning

For a further exposition see Jürgen Backhaus, Handleiding voor een economische analyse van een juridisch probleem, Hfdt. 12. In: R.W. Holzhauer, R. Teijl et. al. Inleiding Rechtseconomie, Arnhem: Gouda Quint, 1989.

2

In this essay, the analysis of constitutional legal issues is based on the assumption that the constitution is 
beyond the scope of economic analysis, and certainly not beyond the scope of that critical scrutiny an economic analyst can offer. The critical scrutiny should, however, be taken for what it is: a positive statement about consequences, and functions of norms, or relationships between values, not a normative statement on desirable changes or interpretations, and therefore not a contribution to legal constitutional theory. Yet, the constitutional lawyer may benefit from the work of the economic analyst who deals with constitutions.

The structure of this essay reflects the basic problems just outlined. The two main parts of the analysis deal with constitutional guarantees and constitutional change respectively. It is shown what purposes constitutional guarantees fulfill, what happens if they are not present, and how basic constitutional guarantees relate to each other. The part dealing with constitutional change tries to show how an economic analysis would explain and predict these sometimes subtle processes of constitutional change without amendment. The essay starts with an overview over some main lines of law and economics scholarship and concludes with a summary of the main findings.

For an essay of this size, a short reader's roadmap might be helpful. The two main parts of this essay, part I and II are selfcontained and can be read separately. Part I will be of interest for a general introduction, while part II shows how by means of economic analysis constitutional change without amendment can be modelled. Obviously, other modelling strategies are possible. The structure of the assumptions and conclusions of part II is contained in appendix II in concize form, and appendix I reproduces those articles of the three constitutions which were expressly discussed in section 3 of part I.

\section{1. \\ The Economic Analysis of Law: A Short Characterization of Major Concepts and Persons - Calabresi, Posner, and Hayek.}

Law and economics, as a subdiscipline of its own, builds on a number of different classical contributions, which have merged into a unified paradigm but stem from different roots. During the last three decades, the centre for a renewed emphasis on law and economics research undoubtedly has been the University of Chicago and the seminal oral and written tradition established by Aaron Director, Ronald Coase, George Stigler and Richard Posner. These names and the work they represent fall in the hospitability tradition in law and economics. Institutions, or more generally speaking legal customary or social arrangements, are interpreted as facilitating transactions between different economic agents and thereby helping in the production of wealth or, more generally, the improvement of economic wellbeing. This tradition mainly falls into the second type of law and economics analysis, the functional interpretation of institutions based on the premise that, with time and barring obstacles, the law will develop towards efficient arrangements. Although constitutions are not in the centre of this approach, the analysis of constitutional rules and arrangements can be important for law and economics analysis in the Chicago tradition in as much as constitutions lay down the framework for the

indeed considered as legitimate. Imposed constitutions not considered as legitimate by the people, the judiciary or else an important part of society pose additional analytical problems beyond the scope of our discussion. 
development of the (common) law. The vantage point from which constitutions are analyzed in terms of the Chicago approach are the functional requirements of market based transactions with respect to the development of the law. To put it in the most simple terms, the constitution must provide for a framework of legal institutions, such as courts, legislatures, and the professions which allows for an open arena in which the law can be improved upon in the interest of economic progress in society.

Where there is a tradition of hospitability, we also expect a tradition of inhospitable hosts. ${ }^{3}$ Inhospitability characterizes an attitude which starts form a simple model of market exchange and treats complex legal arrangements, such as complex contractual arrangements, as observations, likely conceived in order to suppress competition. This is the traditional area of law and economics or antitrust economics, which in its simple forms is nothing but subservient to the traditional requirements of defining such terms as "competitive behaviour" and "relevant markets". In its more sophisticated appearance, it is linked with the ordo school of analyzing economic systems comparatively; by taking a systems approach, the school was able to derive a set of necessary conditions for a competitive order. These conditions taken together as a whole form the economic framework for the competitive order, i.e. the constitution of the economic system; and the operation of the economic system is greatly facilitated if the conditions can be found among the constitutional guarantees contained in the basic document by which the legal culture of a country abides. The six conditions are:

1. freedom of contract;

2. guarantee of private property;

3. synchronization of control and liability;

4. constancy and predictability of economic policy;

5. provision of a stable currency;

6. $\quad$ open access to markets. ${ }^{4}$

A second and prominent strand in modern law and economic analysis is associated with Yale Law School and Guido Calabresi, whose approach, as pioneered with his classical analysis of the costs of accidents, ${ }^{5}$ sets out a clearly stated policy goal and explores different legal policies in terms of that goal. In his classical analysis, the purpose or goal was the minimization of the sum total of costs incurred in a society as a consequence of accidents. Different costs were distinguished, such as the primary or inmediate costs of accidents, the secondary costs or costs of dislocation, and the tertiary or administrative costs associated with running a particular system of accident law. The different

The terms are Oliver Williamson's; see e.g. Oliver E. Williamson, "The Modern Corporation: Origins, Evolution, Attributes". Journal of Economic Literature XIX.4, 1981, pp. 1537-1568.

See e.g. Wernhard Möschel, "Corporation Policy From an Ordo Point of View". Ch. 7. in: Alan Peacock and Hans Willgerodt (eds.0, German Neo-Liberals and the Social Market Economy. New York; St. Martin's, 1989, pp. 142-178 (154-155).

See Guido Calabresi, The Costs of Accidents: A Legal and Economic Analysis. New Haven: Yale University Press, 1970. 
approaches to containing the costs of accidents such as the common law approach of tort liability, the penal and administrative law approach of barring or regulating particular accident prone activities, and the social security approach of containing dislocation can then be evaluated in terms of the overriding goal. The approach can essentially be used for any type of legal policy problem, and it is relevant from the point of view of constitutional legal analysis in that it treats the legal system as largely malleable.

A third approach which is much less dominant in modern law and economics scholarship while very important for the economic analysis of constitutional rules is associated with the name of Friedrich Hayek and merges the theory of economic policy with the ordo and Austrian traditions to economic analysis. ${ }^{6}$ The strength of this approach lies in the systematic integration of legal policy into economic policy. Ambitious economic policy programs are analyzed in terms of their informational requirements; and legal arrangements, often at the constitutional level, are suggested for safeguarding and implementing these policy measures. Although the approach is general, it is sufficiently tuned into both economic and legal discourse in order to allow for very specific conclusions when applied to specific cases. $^{7}$

Finally, it is important to mention the constitutional analyses in the tradition of public choice. Here the underlying question, as pioneered by James Buchanan and Gordon Tullock, ${ }^{8}$ is the following: What are the likely outcomes of basic constitutional rules? and, consequently, if I had to choose behind a veil of ignorance about my future position in this world, which constitution would I opt for? Although the approach is hypothetical, in that we can never abstract totally from our own experience and expectations, analytically it is extremely fruitful in reducing sometimes complex legal rules to their bare essentials.

\section{Constitutional Guarantees}

Constitutional guarantees refer to either basic rights enjoyed by natural or legal persons or procedural requirements or a set of such rights or procedures or a set of such rights and procedures. Since a constitution tends to be a carefully crafted document, it is important to look at the system of guarantees it stipulates by guaranteeing basic rights and procedural relationships. The first section of this part will be devoted to basic rights, and the second to procedures.

Friedrich A. Hayek, Law, Legislation, and Liberty. Vol. 1-3. Chicago: University of Chicago Press, 1973, 1976, 1979.

See for example Jürgen Backhaus, Mitbestimmung im Unternehmen. Göttingen: VandenHoeck \& Ruprecht, 1987 (part B) for an application to the German codetermination act of 1976 and the subsequent decision of the constitutional court of 1979

See James M. Buchanan, Gordon Tullock, The Calculus of Consent. Ann Arbour: University of Michigan Press, 1962. 
The most straightforward way in which an economist can assist in solving a problem of constitutional law is in assessing the consequences of a particular guarantee or the repeal of such a guarantee. The daily press offers numerous examples. What is the consequence of extending the guarantee of private property rights to both nationals and aliens? The economy will take on a more international character than otherwise. What is the consequence of guaranteeing privacy? More knowledge will be accumulated that can thereby be protected. ${ }^{9}$

More difficult is a functional approach to analyzing constitutional guarantees. The difficulties arise mainly because simple models of economic behaviour cannot be invoked. The economic function of a constitutional guarantee depends crucially on the style ${ }^{10}$ of a particular economy and is therefore not invariant across legal cultures or economic styles. For instance, the guarantee of private property in means of production takes on a different significance depending on whether one positions this constitutional guarantee into the context of an economy under early capitalism or whether one refers to the same guarantee in the context of an advanced welfare state with ingrained employment policies by means of the tax-subsidy instrument mix.

Next to specifying the economic system in which a particular constitutional guarantee deploys its effects, it is important from an economic point of view, to specify precisely those dimensions of the constitutional guarantee which are economically relevant; in seperating them from others which are not. The case of private property can serve again as an appropriate example. From an economic point of view, private property is much too crude a term as to afford economic analysis with reasonable precision. From an economic point of view, the important aspect is that the definitions of the various elements of a property right can be effected with sufficient precision and sharpness, so as to allow for an optimal partitioning of property rights in terms of the specific needs of transactions of widely different natures. Consider the importance of partitioning property rights in corporations according to

9

See Richard A. Posner, "The Law and Economics Movement" (Richard T. Ely Lectur). American Economic Review Papers and Proceedings, 47.2, 1987, pp. 1-11.

10

The concept of "style" of economic conduct is a key notion we owe to the historical school. It was used by Schmoller, Sombart, Spiethoff and Schumpeter, who took style as a term of economic sociology. In order to understand and correctly interpret economic phenomena, one may want to look at the leading ideas and convictions (spirit) to which people subscribe and which will guide their actions; secondly at the techniques at their disposal; and thirdly at the organizational forms in which means and ends are combined or, alternatively, in which spirit and technique find their institutional realization. Spiethoff actually gives five categories, i.e. the economic spirit, the natural and technical resources, the constitution of society, the constitution of the economy, and the economic process. For details see Arthur Spiethoff, "Die Allgemeine Volkswirtschaftslehre als Geschichtliche Theorie: Die Wirtschaftsstile'. In: Arthur Spiethoff (ed.), Festgabe für Werner Sombart zur Siebenzigsten Wiederkehr Seines Geburtstages. Neunzehnter Jänner 1933. München: Duncker \& Humblot 1933, pp. 51-84 or Bertram Schefold, "Die beiden Wege'. In: MeierAbich/Schefold 1981, pp. 133-162. 
capital investments of different priority and standing, human capital investments, securities granted in order to allow for certain transactions to be feasible, etc. The precision with which the economic analysis will have to proceed may by far exceed what is typically wanted in legal discourse.

The normative analysis of constitutional guarantees is the classical domain of political theory. Economic analysis of constitutional guarantees differs from the analytical approach taken by political theory in that its normative conclusions are conditional upon normative assumptions; they are simply the logical implications of certain assumptions which are chosen for being innocuous. The technique of simulating a choice behind a supposed veil of ignorance ${ }^{11}$ mentioned above is a typical example for this logical procedure. Starting from the basic postulates of equality and social solidarity in the sense of assisting the worst off member and invoking, in addition, uncertainty about future events (which is what the principle of solidarity is about), an outcome is derived which allows for substantial inequalities in ex post endowments. This apparently paradox result can turn out to be quite important in judging the merits of pieces of social or tax legislation in the light of constitutional guarantees.

\subsection{Basic Rights}

\subsubsection{Freedom of Contract}

From an economic point of view, freedom of contract is an important guarantee because it ensures as a necessary condition, that all the information available in a society enters economically relevant decisions and all the resources available in a society will be put to their most efficient use. This implies that every infringement of freedom of contract has to be judged in terms of the losses imposed on society due to ignorance and wasted resources. From an economic point of view, it is not sufficient to weigh freedom of contract against some other guarantee such as the principle of equality as such, without paying attention to the full consequences of the trade-off. If for instance it is observed that in a certain society members of a minority are not represented in a particular profession according to their numeric share in that society, from an economic point of view it is not justified to pit the observed endstate inequality against the guarantee of freedom of contract, since a rational choice in the interest of all parties concerned may have led to the unequal outcome. An economic analysis would have to inqire into the reasons for the observed inequality, and it would lay the foundation for assessing the trade-off between the social (opportunity) costs of constraining freedom of contract on the one hand, and the gains in terms of economic equality on the other. Based on the inquiry into the causes of the observed inequalities, an alternative strategy to improve the chances of the minority in question can in all likelihood be derived. It is at this instance that the economic analysis of constitutional guarantees can have implications for constitutional law. Many constitutions require that basic rights can only be curtailed if less onerous measures are not available. To the extent that economic analysis can yield the design of such less onerous measures, it changes the constitutionality of particular policies.

\subsubsection{Private Property}

See John Rawls, A Theory of Justice. Oxford: Oxford University Press, 1971. 
The guarantee of private property is most important with respect to the means of production. Again, from an economic point of view, the guarantee goes far beyond the protection of people's possessions of goods and services. The reason is fairly straightforward. In economics, property rights define and circumscribe alternatives for meaningful actions. Hence, the mere property title to some good, such as land, is meaningless if it does not imply discretionary alternatives and options that can be exercised.

In particular, the guarantee of private property rights implies the right to exercise private property prerogatives within workable institutions. The guarantee is violated if, for instance, the contractual forms in which a property right can be exercised are unworkable or impractical, thereby destroying the value of the property right or seriously reducing it. The institutions in which private property rights can be exercised have to provide for the possibility that the four standard options of economic conduct ${ }^{12}$ remain open. These options include:

1. exit, the right to end an economic relationship;

2. voice, the option to meaningfully improve upon a relationship by changing it through negotiations;

3. loyalty, the ability to foster the growth of trust and goodwill in a relationship even in the face of serious problems, and

4. avoidance, the option to ignore a particular relationship altogether without facing sanctions.

\subsubsection{Liability}

The two basic rights of freedom of contract and private property need to be complemented by the institution of liability in order to be meaningful at all. The faithful observance of contractual terms needs the protection of a shield of liability for failure of living up to contractual terms just as much as the respective private property rights require the need to make the intruder liable. Although this principle is straightforward, from an economic point of view the implications can be far reaching. In particular, liability can only be assigned if the agent to be held liable was in control of events that led to the liability. If this is not the case, the claim has to be followed through all the way to those who were either in control or created the situation that made control impossible. If for instance a patient suffers a serious injury because a doctor did not administer the necessary treatment, which he failed to do because, in order to administer the treatment, according to state regulations he needed the written consent of two colleagues whom he could not reach because they were tied up in meetings, this doctor is not liable for the injury imposed on the patient; nor is the full damage to remain with the patient; rather, the principle of syncronizing control and liability requires to make those jointly and severally liable who contributed to passing the regulations causing the problem - tying up doctors in meetings and requiring written consent to engage in professional activities - in the first place.

\subsubsection{Stable Legal Environment}

For an analysis of the importance of the first three options see Albert O. Hirschman, Edit, Voice, and Loyalty: Purposes to Decline in Firms, Organizations, and States. Cambridge: Harvard University Press, 1970. 
The following three basic guarantees are more or less ancillary to the first three, the classical threesome of economic basic rights. Constancy and predictability of economic policy is required in order to be able to enter contracts covering not only the present but also the future. The same is true with respect to the exercise of property rights with consequences in the future, notably investment decisions. For private property rights, however, the predictability of economic policy, is crucial because it affects the adjustment costs necessarily borne by the private sector and falling onto property, conceivably reducing its value. This requirement does not affect the range and domain of economic policy, but only the time horizon within which it can be carried out. The more predictable economic policies are, the smaller the adjustment costs. The corrollary statement requires, that the more drastic a policy change, the longer its implementation has to be delayed and the more carefully the precise contours of the new policy have to be explained in order to allow for smooth adjustments in the private sector. A policy may be unconstitutional simply because the legislature did not take the requisite care in spelling it out in time and providing for reasonable adjustment periods before implementation.

\subsubsection{Stable Currency}

Contractual relationships that are entered into for longer periods of time typically require for some kind of payment to be made by one or the other party. The benefits from contractual relationships can be seriously impaired if there is no common language in which to express the duties of the different parties. The problem is most serious in the case of payments, if there is no stable unit in which to express the size of payments to be made and received. The more uncertainty there is, the smaller can be the gains from trade and consequently the smaller is the potential for economic progress in that society. This is why, from an economic point of view, the guarantee of a stable currency is important as an ancillery right. Again, what is really required is not one particular monetary policy, but rather an institutional arrangement which stabilizes the unit of account. It should be noted here that this requirement does not prescribe any particular monetary policy for a central bank; nor does it require only one currency to circulate in a particular market. Leading monetary theorists have shown that a variety of currencies circulating may not only be compatible with the principle of keeping the unit of account stable; it may even be in the interest of enforcing this principle. ${ }^{13}$

\subsubsection{Open Markets}

Finally, access to markets has to remain open in order to allow for other basic human rights to be exercised in a meaningful way. This is obvious for the right of freedom of contract, but also extends into such classical basic rights as the freedom of the press, freedom of political expression, freedom of exercising the religion of one's choice, freedom of exercising the profession of one's choice, the academic privileges of freedom of instruction and research, etc. The problem is, by the way, most

See for instance for a short statement Leland B. Yeager, "Deregulation and Monetary Reform". American Economic Review, Papers and Proceedings, 75.2, 1985, pp. 103-107 with further references. 
serious if a particular government or some private agents suppress the existance of a market altogether. The guarantee of freedom of access to markets obviously includes the guarantee to have such markets established, which does not predetermine the shape such markets take, as long as they provide for an open forum to communicate and exchange, which is what a market basically is about.

\subsection{Procedural Guarantees}

Basic rights and procedural guarantees are equally important, since basic rights can only be exercised if certain procedural guarantees are observed. The importance of procedural guarantees is not reflected in the amount of space they receive in this essay, due to space limitations. Essentially, there are two types of procedural guarantees: guarantees regulating the relationship between public bodies; and guarantees regulating the relationship between public bodies and citizens.

\subsubsection{The Relationship between Public Bodies}

The procedural principles regulating the relationships between public bodies consist of at least three groups. They include all those rules regulating the domains of competence of the various public bodies with respect to each other, including the areas of cooperation, mutual consent or hierarchical control. A second group consists of principles of budgeting such as the principles of timeliness, completeness of budgets etc. A third involves principles of legislation. One is that legislation always has to be of a general character, and that acts are invalid if they address one case only. Another economically relevant principle involves the requirement that legislation which has turned out to be faulty, unjust or seriously impractical and thereby has turned out to be in violation of basic rights needs to be corrected.

\subsubsection{The Relationships between Public Bodies and Citizens}

The second set of procedural rules typically found in constitutions involve the question of how the private citizen or legal entity relate to public bodies. Into this category fall essentially two sets of rules. One set again governs the separation of the domains of competence. A typical example is the separation of church and state. But here, again, forms of cooperation, of mutual consent or of hierarchical orderings are clearly available. The second set of rules, generally described by the extremely comprehensive term of due process, lays down the rules of the game between public bodies and private citizens or legal entities. These include informations rights, notification rights, and the right to have access to courts and bodies of appeal in meaningful ways that go beyond merely procedural ceremonies without content, since the important bench mark is the effectiveness of these procedures in safeguarding the six basic economic rights outlined above.

\subsection{A Consize Summary}

In the proceeding analysis, we have identified constitutional guarantees with respect to basic rights on the one hand and procedural rules on the other. There are three basic rights the guarantee of which has to be considered as central from an economic point of view. These guarantees protect the right of 
freedom of contract, the institution of liability in the sense that those responsible for actions or a lack thereof can be held responsible for the effects of their activities or the lack thereof; and the institution of private property in the sense that clearly specified and meaningful alternatives become available for economic agents to dispose with goods and services. These basic economic rights are supported by three ancillary economic rights, guaranteeing a stable legal environment, a stable currency providing for a common language of contractual relationships, and open markets which include the right to establish such markets in areas where they don't exist.

Procedural guarantees cover either the relationship between public bodies, or the relationship between public bodies and private citizens or other legal entities. The principle of due process requires in this context that citizens and legal persons have access to courts and bodies of appeal in meaningful ways, barring purely ceremonial procedures.

The economic analysis of constitutional rights can, obviously, not substitute constitutional jurisprudence. But economic analysis can substantially enhance the sharpness of jurisprudential analysis by spelling out the consequences of particular constitutional provisions (or the lack thereof) and the systematic interconnections between basic legal institutions such as property, contract, and liability; as well as legal procedures. In this sense, the economic analysis can be integrated into jurisprudential analysis and by being embodied into the interpretation of constitutional provisions, economic analysis can become an integral part of constitutional scholarship.

\section{Applications to Three Constitutions}

The apparent paradox that, on the one hand, constitutions are written so as to provide immutable standards of the law and, on the other hand, have usually proved to be sufficiently flexible so as to be retained over a period of perhaps several centuries under greatly differing legal, economic and social circumstances can be explained by looking at the underlying process of constitutional change without amendment. A closely formulated model of possible scenarios for this form of constitutional change is spelt out in section IV. A more general and necessarily less precise discussion is offered in this section with respect to three different constitutions. It is shown that the source of constitutional change without amendment lies in the selective interpretation of single constitutional guarantee which can lead to significant alterations of the end result if the system of guarantees of rights and procedures is not closed or when, alternatively, some of its elements are neglected in the interpretation.

\subsection{The U.S. American Constitution of 1788/92}

The early history of the U.S. American Constitution provides an illuminating illustration of the principle spelt out in the previous paragraph. Alarmed not by what the Constitution contained but by what it did not, leading statesmen such as George Mason refused to sign the document. Thomas Jefferson, then Minister to France, urged President James Madison to include a Bill of Rights providing clearly for freedom of religion, freedom of the press, protection against a standing army and restriction against monopolies. After a process that took several years, on March 1, 1792 now Secretary of State 
Thomas Jefferson could announce the ratification of the requested amendments to the constitution to the governors of the States forming the Union.

As we look at just these first ten amendments, commonly known as the Bill of Rights, we notice immediately why the ten amendments made such a big difference in getting the constitution ratified by the States. The overriding concern is to prevent a central government from emerging as a center of power in society, and every one of the amendments contains a different strategy to achieve this end. The first amendment establishes a market of ideas and prevents the government from either interfering with this market or even participating in it in so far as religion is concerned. It is clear that this market of ideas is expected to serve a political function, since the ancillary right to petition the government is immediately connected to a guarantee of freedom of speach and the press. The second amendment characteristically ties the State's prerogatives to maintain a well regulated militia to the peoples' rights to bear arms, both aimed at the protection of basic constitutional rights, in particular property. It is noteworthy that the amendment explicitly prevents a State monopoly to use armed force. That monopoly is shared with the individual citizens as the people, always pitted against the State. The third amendment, more specifically protects the integrity of the house as the central seat where property rights are exercised against State power as it is represented by the army; while the fourth amendment protects the integrity of the house by tightly regulating the conditions under which the State may enforce the legal order.

Whereas the first five amendments circumscribe the way in which the State may exercise its lawful prerogatives, denying the State a monopoly to violence, the second set of amendments (six to ten) deals with the source of the law, again denying the State a monopoly as being the only originator of the rule of law. The sixth amendment establishes the jury as an important source of the law. This can provide for considerable discrepancy in jurisdiction between the different areas of the Union, an intended result. The seventh amendment extends the principle of jury trial from criminal law to the common law as a whole, again taking the development of the law out of the hands of the State. The eighth amendment underscores this principle again by constraining bail, fines, and all other forms of sanctions for them to be in line with what is generally conceived to be the consensus in the people, not with State authorities. As if this was not enough, the ninth amendment even provides a principle of constitutional interpretation, squarely distrusting the wisdom of the professional lawyer. The rights of the people have to be broadly interpreted, while the prerogatives of the central State need to be narrowly interpreted, with either the States or the people at large being the beneficiary of this mode of interpretation (tenth amendment).

The architecture of the Bill of Rights clearly reflects their authors' understanding of the interdependence of constitutional guarantees. In the center, amendment five contains a full and sweeping guarantee of the basic human rights to life, safety, liberty and property; these personal rights are immediately safeguarded against government interference by requiring jury trials on the one hand, just compensation on the other. This indicates the two wings of the farflung system of defense designed by the authors of the Bill of Rights: vesting the foundation of the law in the people, unless otherwise 
prescribed by the constitution, and vesting the exercise of public powers with the State or the people, again unless otherwise prescribed by the constitution.

The language of the Bill of Rights seems to be in striking contrast with the farflung activities of the American federal government. The question arises why given the systematic integration of the various principles of the Bill of Rights and the very plain language used such a discrepancy could ever emerge. If we go through the list of the basic guarantee outlined in the preceeding section, we find freedom of contract, private property and stable legal environment (witness the extensive regulation of jurisdic tion) wonderfully spelt out and guaranteed. While a stable currency is not explicitly guaranteed, it has not emerged as a problem during the last one hundred years. Open markets are definitely guaranteed through the fifth amendment.

The source of the problem is readily revealed when we consider the types of infringements anticipated. Infringements were anticipated as deviations from an orderly conduct of government which could be challenged before a jury by insisting on the observation of those rules underlying government activity; and holding those responsible who had deviated from the letter or spirit of the law. Never could the framers of the Bill of Rights have anticipated the emergence of a government organization which can avoid political or legal responsability by following the letter of the law. The principle of bureaucratic organization is just that: the disposal of responsability by adhering to general rules which are implemented in a way not challengable in any court. The modern bureaucratic State can enter the privacy of the house without a search warrant, can take away private property without notice or just compensation (or any compensation whatsoever), can deprive people of their chances of life or health for instance through decisions on allocation in public health care provision, can deprive a citizen of liberty without due process of law, can take private property for public use without compensation or impose cruel and unusual punishment (amendment eight) - for instance by entangling single citizens in bureaucratic procedures which, although perfectly correctly followed, may still amount to unequal and excessive punishment.

The principle violated here is the third principle requiring synchronization of control and liability. The modern bureaucratic organization of the State, and most notably the centralized State, is characterized by the opposite of this principle, by the dissynchronization of control and liability. In their relationships with public bodies, individual citizens often find their private property unprotected, because the fourth option identified above, the option to avoid the public agency altogether, is often denied. While the costs of exit tend to be high, many modern governments try to reduce the costs of voice, by for instance instituting the office of an ombudsman in their organization. The option of loyalty obviously is a traditional main stay of public organization, but it is useless if a meaningful alternative to loyalty, avoidance, is not open.

\subsection{The Constitution of the Federal Republic of Germany of 1949}

The constitution of the Federal Republic of Germany of 1949 contains one of the most elaborate catalogues of basic rights one could imagine. Yet, the tension between a Federal State with democratic 
procedures of decision taking and a bureaucratically organized executive on the one hand, basic citizens' rights on the other we found in the Bill of Rights of the United States of America has been avoided. Next to guaranteeing citizens' rights, the German Basic Law leaves no doubt about the political structure superimposed on the people. The State is immediately characterized as a Federal State following democratic principles and having a social purpose (article 20), political parties are guaranteed by the constitution (article 21) and the basic citizens' rights are in any event guaranteed only in so far as their institutional core is concerned, since they might otherwise be found to conflict not only with each other but also with the social purpose of the Federal State. This is most clearly seen in the guarantee of private property (article 14) which is immediately followed by the exemption of article 15 which allows for the socialization of means of production. Whereas normally, private property can only be taken with just compensation (article 14.III; see also the fifth amendment), "just" is specified to mean a compromise between the interests of the parties involved and the general interest. Since the socialization of the means of production can only take place, de jure in the general interest, just compensation under article 15 certainly means less than the just compensation under the fifth amendment. ${ }^{14}$ The most striking provision is perhaps the opening to further federations, no doubt sparked by the country's sad history. By opening the possibility of additional memberships, the constitution is put to a test [see article 23]. However, the provision is weak insofar as it does not take account of the "international political situation" which ultimately offers the limit to any constitution writing.

The case of (West) German constitutional law is particularly interesting, since the view (elaborated above) that constitutional principles derived from economic analysis might form a part of constitutional doctrine has been expressly addressed by the Karlsruhe Constitutional Court. In a series of cases, the view based on the teachings of the German ordo school of economics that a market economy requires the observation of a series of constitutional principles was tested for the German Basic Law of 1949 with the proposition that the basic law of '49 provided for the establishment of a market based economy. This view was based on article 2.I, a general principle of personal freedom, containing the freedom of enterprise, the freedom of competition, the freedom of contract doctrine, the freedom of production, consumption and price formation, in conjunction with the guarantees of the freedom of association (art. 9), the freedom of exercising the profession of one's choice (art. 12) and the guarantee of private property. In this form, the view was flatly rejected by the German constitutional court. ${ }^{15}$ Consistently, the court has held that the legislature is free to decide on the economic order it wants to adopt for the different sectors of the economy, while it has to observe the basic rights just as much as the mission outlined in article 20. However, the court has also held, especially in more recent decisions that the legislature is not free to decide on any economic order it may fancy. Legislated institutions have to be workable, and the deliberation of the likely results of legislation wrought with

14

For details see section IV of this article.

See for instance BVerfGE 4,7; 7.377 (400); 12, 341 (347). For futher details, see Jürgen Backhaus, Öffentliche Unternehmen, Frankfurt, 1980 (2), section 50. 
uncertain consequences has to be particularly careful, taking full account of the state of (economic) science. If a piece of legislation turns out to be unworkable, it has to be repealed or amended. ${ }^{16}$

This implies that the German constitutional court recognizes an important role of the economic analyst. ${ }^{17}$ If his analysis points to unintended or unanticipated consequences of the legislation, the legislature has to take these results of scholarly analysis into account.

\subsection{The Dutch Basic Law of 1983}

The Dutch Basic Law is a special case in that its bill of rights is extremely vague, essentially with one exception. The exception is article 1 which postulates the principle of equality for every resident. The typical formulation of the individual rights contained in the first part of the Basic Law postulates the respective right in principle, but subject to (simple) legislation (arts. 2, 4, 6, 7, 8, 9, 10, 11, 12, 13, etc.). The most interesting case is article 14, which contains an implicit guarantee of private property, but speaks exclusively of taking under various circumstances with various degrees of compensation. About one third of these basic guarantees involve the "social human rights', detailing various areas of policy, such as employment policy, as tasks of the government. These rights start with the right to petition (art. 5), also contained in the American Bill of Rights, continue with the government's task to conduct employment policies (article 19), to be active in social security and welfare (article 20), in environmental affairs (article 21), in public health and housing (article 22) and education (article 23). Again, this article is interesting in that it does not contain any explicit guarantee of the classical academic privileges (freedom of learning, freedom of research, freedom of instruction). Article 23, which a superficial reader might interpret as such a guarantee, is quite obviously only concerned with schools, their supervision and their financing. The Dutch term research (onderzoek) appears not in the context of a guarantee of the freedom of research, but in terms of giving the government authorities the right to investigate ("research") the qualifications of teachers. Also, while the ancillary right of the freedom of the press is guaranteed (article 7.1), the wording is not helpful to the publication of unwelcome research results, since it excludes only the need for prior clearing, not post publication censorship. This implies that the right is tailored to guarantee freedom of political expression.

The conclusion must be that it is hard to imagine any kind of important conflict of indidvidual rights with government prerogatives which, under the Dutch Basic Law, would not have to be decided in favour of the government. The inbuilt tension of the American Bill of Rights between individual liberties and the rights of government is not present.

16

See Jürgen Backhaus, Mitbestimmung im Unternehmen, Göttingen: Vandenhoeck \& Ruprecht, 1987; and see BVerfGE 50, 1979, 290.

17

At least since the Brandeis brief, similar conclusions hold for the United States as well, but they have never been as sharply accentuated as in the German case. 
Given this situation, one has to agree with Ten Berge ${ }^{18}$ that economic analysis of constitutional law is difficult with respect to the Dutch basic law, since there are so few starting points. However, the vagueness of the Dutch constitution is only the reverse of the same coin, which grants the government, and notably the central government a wide discretionary leeway. This leeway is not unstructured, but filled with a host of consultative organizations aiming at reaching some kind of agreement with government. The result is that legislation tends to be multifacetted and rarely streamlined. The Dutch political culture is therefore much more open to using analytical concepts to re-evaluate legislation in terms of its intended effectiveness. Instead of using constitutional guarantees as the measuring rod of economic analysis of particular pieces of legislation, the intended (and stated) purposes of the legislation can serve as the bench mark; the remainder of the analytical procedure remains intact.

In addition, Dutch courts have increasingly come to acknowledge citizens' rights contained in international treaties ratified by the Kingdom. A similar trend can be observed for the United Kingdom which does not have a constitution at all. In both cases, the European Court of Justice assumes an additional rôle not played in countries with strong bills of rights. These treaties take the role of the Bill of Rights in the United States constitution, or the "Grundrechte" in the West-German constitution, and the same analytical techniques to incorporate economic analysis into constitutional jurisprudence can be used as in those cases.

II

Constitutional Change

4. Introduction

Over the last decade, more and more economists have shown an interest in the fundamental rules of society. ${ }^{19}$ There has been an emphasis on the analysis and derivation of 'optimal' constitutional rules, agreed upon by individuals under conditions of limited knowledge, in order to abstract from present (and presumably 'unjust') states of society, such as the distribution of power, wealth, and opportunities. However, there has been little interest in institutional devices to enforce constitutional rules, whether agreed upon or not, in the context of modern democratic societies. There is, on the other hand, a

See his 'Rechtseconomie en Staatsrecht - Bestuursrecht". In: E.H. Hondius, J.J. Schippers and J.J. Siegers (eds.), Rechtseconomie en Recht, Zwolle: W.E.J. Tjeenk Willink, 1990.

19

See, for example, Buchanan and Tullock (1962), Rae (1969), and Baumol (1965, pp. 39-45). The appearance of Rawls's A Theory of Justice, Oxford, 1971, finally has caused a flood of literature which neither can nor need be cited here. 
growing uneasiness with the social arrangements and institutions designed to protect and enforce the constitutional consensus. ${ }^{20}$

This paper sets out to provide an analysis of the process of interpreting the constitution, by which the constitutional norms are not only applied and adapted to changing circumstances but essentially changed in content. The analysis concentrates on a rather specific example, a norm which has a clearly demonstrable impact on different identifiable interests. The approach is, however, easily generalizable and may be applied to any constitutional norm specific enough to foster a clash of interests. The analysis undertaken is - in contrast to the debate on constitutional issues cited earlier clearly positive. No normative conclusions are arrived at nor desired, rather the analysis seeks to present stategic considerations concerning constitutional litigation. ${ }^{21}$

\subsection{The situation of conflict}

In the Western-style democracies with majority voting procedures and constitutional guarantees to minority groups, ${ }^{22}$ there is always an incentive for vote-maximizing governments to please the majority and take away privileges from the minority, even when it is in the best (long-run) interest of society as a whole to stick to the constitutional consensus.

The constitutional guarantees of individual property may serve as an appropriate example. These allow for expropriation of individual property by the government only in certain cases where the 'public

Buchanan (1975) says: "Political constitutions which are at all explicit normally require more inclusive rules for change in the constitution than for ordinary collective decisions. In practical fact, basic legal rules are modified through long observed but condoned departures from explicit rules, through judicial fiat, through legal precedent, through encroachment by legislature on what should be the seperated function of constitution making, and through numerous other instruments (...). Such non-agreed changes (...) have little claim to be called 'legitimate' (p.116). See, also, with reference to the U.S. Supreme Court, Glazer (1975), and Richard A.. Posner, "The Constitution as an Economic Document". George Washington Law Review, 56 (1), November 1987.

21

These strategic conclusions are, however, not normative but 'technical' propositions.

22

Key elements of this type of society might be: (1) Competition of political parties, (2) majority voting procedures, (3) guarantee of individual liberties, (4) institutional arrangements for the effective enforcement of these guarantees. 
interest' is involved, and only when it is accompanied by 'just compensation' ${ }^{23}$ preventing redistribution. ${ }^{24}$

Well, often an important exception for industrial property is usually included in the constitutional document: "Socialization of land, natural resources and the means of production is (in the European constitutional context) constitutionally viable, and permissible with only trifling compensation necessary". $^{25}$

Somehow, in the course of time, this constitutionally-opened channel of action has a tendency to be narrowed drastically in the normal process of interpreting the constitution.

This strange phenomenon can be illustrated by various examples. As a matter of convenience, I refer to three German cases which have been described in detail and can therefore be referred to in this essay with only a few words. ${ }^{26}$

1. Otto Kirchheimer showed that by means of an extensive interpretation of the guarantee of individual property almost any positive state action had expropriative elements and consequently had to be accompanied by compensations. This extensive interpretation described and criticezed by Kirchheimer was partly sustained by the German Supreme Court ("Reichsgericht") with disastrous consequences, e.g., on urban planning.

23

This tends to be interpreted as meaning the market values of the taken property.

24

In fact, this statement does not completely hold true; as the market value of a particular share lies below the individual valuation by its particular owner - otherwise, he would sell at the prevailing market price - there is some type of redistributing rents occurring. There will be no regard to this in the following, as the argument would only be reinforced by this observation.

25

See, for the Federal Republic of Germany, Art. 15 GG; for the Italian Republic Art. 41 CI.

26

See the brilliant description as early as 1930 by Kirchheimer for the evolution of the interpretation of Article 153 of the Weimar Constitution. Recently, the author of the present study has undertaken to show this tendency for two further cases, Article 41 of the Constitution of the German state of Hesse and Article 15 of the Bonn Constitution. See Backhaus (1976) for a detailed description and analysis of case 2 and 3.

Perhaps, an autobiographical note is in order at this juncture. This research started when I stumbled upon the dramatic ineffectiveness of Art. 41 of the constitution of Hesse of 1946, partly achieved by a campaign involving the brightest minds of German jurisprudence on behalf of the owner of one of the industries to be socialized. My interest was further stimulated once I noticed the drastic change the interpretation of Art. 15 of the German constitution had undergone during some twenty years of commentary. My appreciation of the pitfalls and promises of radical social change by constitutional means was further heightened after studying events in Chile following the constitutional reform of 1970 and the election of Salvador Allende G. to the presidency. 
2. In 1946 the German state of Hesse proclaimed a new constitution, thereby socializing the main parts of its industries. Sponsored legal research established that because of its incompatability with the existing body of legal reasoning, socialization by constitutional (instead of statute law) was impossible, and by casuistic interpretation the impact of the norm was thus reduced that it eventually applied to only one major siderorgical (i.e. iron or steel) enterprise as well as to five smaller railways which had to be highly subsidized.

3. The Bonn Constitution (Art. 15) explicitly allows the socialization of land, natural resources, and the means of production; and the act of socialization has to state amount and procedure of compensations to be paid and granted in order to help the former owners to be reintegrated into the new framework of social property. But it is now established legal 'knowledge' that by far not any means of production is socializable, that the compensation to be paid has at least to be the market value, and that socialization should not only serve but be necessitated by the public interest, which is not only to be determined by the legislature but also by the Supreme Court ("Bundesverfassungsgericht").

The particular example of the socialization of industries is chosen because it illustrates a deep constitutional conflict involving a dramatic clash of far divergent interests. A government pursuing this kind of policy will be 'extreme' in the sense that it will differ markedly from its predecessors. This situation clearly demonstrates the principles underlying the continual struggle of the reinterpreation of the constitution.

In what follows, a model is presented which shows how this constitutional conflict may be resolved with the reconciliation of clashing interests: the resulting interpretation of the constitution described the outcome of the conflict.

The model is intented to generate some insights into the process of the interpretation of the constitution (PIC), which is regarded as a public choice process. PIC determines the exclusion and the inclusion of alternative courses of action to be pursued by government, and this predetermines the actual choice among alternative policies to be made by any administration. Therefore, PIC will sometimes turn out to be a public choice process more important by far than voting and elections.

The particular example used is of interest only insofar as it can serve to illustrate the abstract exposition and allows the empirical corroboration of the postulates derived from the theoretical model. The relevance of the abstract model is not limited to the particular examples cited.

A word on the methodology adopted might be of interest. The line of analysis pursued here is distinct from the most frequently adopted methodological procedures in economic science: postulating assumptions, deriving propositions, subjecting these propositions to empirical tests. In this case, the contentional variations (by interpretation) of constitutional norms are not readily quantified; so the empirical test is not straightforward. 
Therefore, the analysis is shaped to postulate suppositions, which are assumptions subjectable to empirical tests, and conditional premises, which specify the situations, for which the analysis holds. ${ }^{27}$ Also, for reasons specified later, two counterfactual assumptions are postulated; these are called principles. From these suppositions, principles and premises, propositions are derived. If the suppostions postulated hold empirically and the premises are relevantly specified, logically correct deduced propositions must hold true. Verification (lack of falsification) of the suppositions therefore corroborates the propositions. The propositions derived are also testable, however. In view of the difficulties of quantification, it is necessary to resort to 'storytelling'. ${ }^{28}$ This is empirically as sound a procedure as any other which leads to clearly refutable results. Storytelling is most commonly used as a first step in order to enter a relatively underdeveloped area of research and therefore is appropriate also in this case. The disadvantage is, however, that you cannot tell as many stories as may be needed to meet common statistical standards. Moreover, the effort of checking the results is higher (especially because of the language barrier), but the same holds true for much of the statistical material usually presented. $^{29}$

\subsection{The system}

The task of the authentic interpretation of the constitution in Western-style democracies is constitutionally ascribed to the judiciary, especially to the Constitutional Court; but it would be grossly misleading to think of this court as the socially unconnected, uninvolved, and independent interpreter of old texts in search of answers to modern questions, as might be believed if one took popular philosopies at face value. The authentic interpretation of the constitution is to be seen rather as the output of the complex system of the interpretation of the constitution (SIC).

On the demand side, this consists of parties interested in an authentic interpretation as a means of resolving their clash of interests. (In terms of Figure 1, this constitutes the system's shell).

On the supply side, we have the constitutional judiciary, which finally resolves the conflict pronouncing its verdict, together with the producers of alternative interpretations. (These form the core of SIC).

27

The word 'assumption' is avoided in this context, because in Friedman's (1953) succession, it is commonly believed that assumptions need neither be tested nor testable. In this model, however, the testability of the assumptions employed is essential for the reasons stated above. Criticism should therefore center on the empirical validity and explanatory power of these testable assumptions. Therefore, the empirically testable assumptions used are preferred to be called 'suppositions', following a suggestion made by James M. Buchanan.

28

For details of this procedure, see Ward (1972, ch.12).

29

For the propositions derived in this paper, evidence in the form of three stories told can be cited. See N.8. Similar examples could, of course, also be referred to (e.g., the legal disputes under the Allende administration in Chile 1970-1973), but space limits forbid this at the moment. 
The system might be illustrated as in Figure 1. The diagram describes the situation: the core of the system consists of the legal institutions for the interpretation of the constitution, while the shell represents the interested parties, who seek to influence the contentional output of the inner system: the core.

Figure 1. The system of the interpretation of the constitution (SIC). 


\section{The actors}

The eventual outcome of the power struggle between government, trying to pursue its policy of redistribution via expropriation, and the proprietors, trying to defend their interests, depends on the behavior of the various actors involved. The next step is therefore to describe the different actors' behavior.

\section{The system's shell}

It is observed that the interested parties will try to influence the process not only by means of appearing in court and presenting their arguments (which is abvious and legally required) but also by influencing the scholarly community, generating alternative interpretations of the constitution. Behavior of the interested parties will be governed by strategic considerations with respect to the desired interpretations. This is a behavioral assumption, denominated Supposition 1 (strategic litigation).

The executive in this model is assumed to be primarily and unambiguously interested in pursuing its predetermined policy. This policy is further assumed to be 'extreme' in the sense of leading to constitutional conflict. In our example this policy aims at expropria tion of industrial property.

In this case, two problems arise:

Supposition 2 (legitimacy deficit). An extreme government, recently come to power, will face a deficit of legitimacy and so be anxious to avoid a defeat in the constitutional court. A legitimacy deficit is defined as the difference between formal political power and effective policy potential. The legitimacy deficit is positively related to the degree of the government's extremeness. Furthermore, it is negatively related to the period the government holds power without its legitimacy being openly questioned. This supposition therefore loses importance the longer an administration stays in power.

Legitimacy might be generally considered as the non-pecuniary ability to attain desired outcomes in public choice processes. ${ }^{30}$ Individuals, lacking further information, expect a correspondence between their wishes and the activities of the party or group to which legitimacy is attributed.

Usually, legitimacy of a government will mainly depend on the way it came to power. In this essay, it is, however, assumed throughout that the extreme administration came to power according to the procedures established by both the constitution and the tradition of that particular society. (Otherwise, the dispute over the interpretation of the constitution would be almost meaningless).

A significant gap between formal power (e.g., majority of votes in parliament) and actual potential to attain a desired result in the public choice process might occur, when structural change (which has components of a public good) is in principle desired by a majority of voters, while particular changes affecting identifiable, organized, and well-defined groups will be oppossed by these groups. Insofar as 
a program of structural change consists of a whole set of particular policies, majority approval of the whole program may be combined with majority opposition to any one part of it.

An extreme administration, differing markedly from its predecessors, will face this dilemma: on the one hand, everyone expects - and a majority authorized - a policy of structural (e.g., institutional) change, while on the other hand this very expectation reduces the correspondence between private interest and anticipated public policy insofar as the policy conflicts with particular private interests.

A legitimacy deficit is accordingly defined as the difference between formal political power and the actual ability to implement a particular policy (against the opposition of the interest groups involved).

Premise 3 (budget constraint). The government in this model faces a budget constraint necessitating use of the constitutional prerogative in question. In view of this constraint, government cannot, in our example, simply buy out the owners of the industries to be socialized. In our example, the observed budget constraint has a specific interpretation. The payment of considerable compensation would counteract the effect of redistribution of power and wealth and would therefore directly contradict the aim pursued.

Bureaucracy's role in this case is far from unambiguous. The bureau involved is in the ministry of justice (attorney general); its officials are occupied with specialized activities, covering the preparation of acts to implement government's policy, negotiations with proprietors' representatives and finally government's litigation and the preparation of the case in court. The top official is clearly dependent on his success in implementing the governing party's policy. He will suffer considerable damage if the political executive finds out that he did not facilitate the achievement of the executive's ambitious (extreme) policy. The head official, however, will face serious difficulties when it comes to his staff. As Anthony Downs observed, bureau's use ideologies as a means of coordinating and harmonizing the various activities undertaken by the office (1967, ch. 17). The bureau concerned in this example fits the one envisioned in Downs's analysis. It is rather large and undertakes a wide variety of rather specialized and not easily controllable activities. In this case, a coherent and sound ideology is vital for the proper functioning of the bureau. However, when suddenly a bureau's ideology becomes outmoded, the central mechanism of coordination breaks down. This will certainly be the case in our example, because the new and extreme administration has to take over its predecessor's bureaucracy. Adopting, changing, and transforming the old ideology to a more suitable one which meets the new requirements is a time-consuming activity. Meanwhile, the bureau is not totally at the head official's disposal. There will be inconsistent behavior and an adherence of staff officials to the former party's political aims. This results in Supposition 4 (ideological delay). Bureaus harmonize the actions of their various officials and departments by means of specific bureaucratic ideologies. To implement a new ideology is a time-consuming activity. Similarity between the government's and the bureaucracy's ideology is positively related with the length of the government's stay in power. ${ }^{31}$

In the context of this model, ideology is not only relevant to bureaucracies. Ideologies might also govern the behavior of the interpreters of the constitutional norms as well as the judges in deciding on the 'authentic' interpretation of the constitution. These aspects are, however, omitted from the 
It is in the owners' interest to protect their property. Given an impending expropriation, they will at least try to gain maximum compensation (This is, of course, precisely what government cannot offer see Premise 3 (budget constraint).)

Both defense of individual property and pursuit of maximum compensation can be achieved by means of challenging the government in court and preparing the legal ground in one's own favor. Apart from investing in the protection of the endangered property, owners may try to liquidate the property and try to transfer it into non-expropriable forms of property or consumption goods.

In an extreme case where expropriation is certain - i.e., where legal activity will not prevent the implementation of government policy - such activity may nevertheless be useful, insofar as the level of compensation has yet to be determined. In this context, investment in non-legal activities (e.g., overthrowing the extreme government) may become more and more important. This political activity alternative will not be considered here. Insofar as this is the case, the analysis is partial. ${ }^{32}$

The higher the a priori probability of losing in court, the more the owners will invest in their legal defense. The result is not as paradoxical as it might seem. The owners maximize the expected utility they derive from their industrial property. This utility clearly approaches zero if they are sure to be expropriated in the near future. In this case, any investment is to them virtually costless as enterprises' debts will be expropriated as well. Thus, in the case of certain defeat, the owner faces a budget constraint equal to the value of his endangered property, the value of which will usually be a multiple of the possible investment in legal defense. The surer is the a priori chance of winning in court, however, the less incentive the owner has to invest in legal defense. In this case, much less defense is in fact needed. This behavioral characteristic might be referred to as Supposition 5 (inverse investment behavior). ${ }^{33}$

\section{The system's core}

Principle 6 and supposition 7 are postulated to describe the behavior of lawyers operating within the system's core.

analysis for simplicity's sake. An analysis of the production of ideologies has been undertaken by Gäfgen (1975).

32

However, there may occur situations in which political lobbying becomes difficult; consider an extreme administration which has recently come to power and is unwilling to have any informal contact with the 'abhorred' enemy (who will certainly direct his efforts toward bureaucracy, inherited from the former, less extreme government).

33

Because of the incomplete analysis of the alternative investment choice undertaken in this context, the inverse relationship holds only partially. 
Principle 6 (non-interestedness). It is assumed here that the core of the system, the judiciary and the scholarly community, is not interested in the matter itself, but acts accoring to some notion of the adequacy of the final solution, and some peculiarities of the 'due process' requisite. This does not imply assumption about altruism or abnormalities with respect to any individual lawyer. It is assumed, on the contrary, the the system is efficiently organized, ${ }^{34}$ in the sense that individual utility-maximizing on the part of the system's members leads to behavior and decisions strictly in accordance with the proclaimed and internalized ideas of the judiciary, i.e. justice and the 'adequateness' of its decisions and rulings. This observation is not very realistic; it is probably counterfactual - but intentionally so. In order to demonstrate the social consequences of using SIC as a mechanism for solving social and political problems and deciding among alternative policies (instead of using other mechanisms, e.g., voting procedures or markets), stress should be laid on the properties of a properly functioning system of pointing to specific failure and judicial idiosyncracies. ${ }^{35}$

Supposition 7 (external impulses). It is observed that lawyers do not decide problems which they pose themselves; on the contrary, the problems they have to solve are posed from outside. For the courts, this is apparent. Courts can avoid problems, but they can decide problems which are not explicitly put before them only to an extremely limited extent (by obiter dicta ruling).

For the legal scholars, this observation is less apparent. I do not know of any research supporting of questioning this supposition. In the absense of any published evidence, it may suffice that the assumption is clearly testable and refutable.

From my own experience, I infer that more than nine-tenths of all legal research undertaken at German universities is externally induced. Most law professors also serve as lwayers in tricky cases which need much research and preparation. All law professors whom I know serve as counsels to a variety of institutions, both public, semi-public, and private. This peculiarity stems from a problem inherent in legal methodology, which can only serve to develop very general principles but for practical reasons cannot solve unposed problems in advance, because the set of actually occurring problems of

The concept of efficiency used here is not social efficiency, of course, but efficiency concerning the system's specific values, as pointed out above.

By the way, this assumption can easily be accepted by lawyers, who would be opposed to the analysis of their behavior in terms of an economist's approach to this analysis; conclusions drawn from this weak assumption are much more interesting because of their general importance. Therefore, there is no need for endangering the interdisciplinary communication between economists and lawyers by postulating assumptions which run counter to lawyers' proffesional ethics, even if these assumptions were more realistic. 
conflicts between different principles and rules is only a tiny fraction of the set of possible problems. Research in advance, therefore, can only be carried out to an extremely limited degree. ${ }^{36}$

The production of alternative ideas stems exclusively from the scholarly community, from specialists in constitutional law, on whose output of ideas the constitutional judiciary, in annually deciding a multitude of cases in various fields, is heavily dependant - Supposition 8 (source of interpretative ideas). ${ }^{37} 38$

This is simply the result of a division of labor, thus permitting specialization and productivity gains. ${ }^{39}$

The scholarly community is affiliated with universities, both public and private.

The constitutional court is formed with judges who cannot be reelected and who have practically been chosen by the political parties according to their strength in parliament. ${ }^{40}$ The court's prerogatives are only vaguely laid down in the constitution itself, but more precisely in the court's fundamental statue, which is open to amendments by a simple majority decision of parliament. The judges will be former university professors and high-ranking officials, and, if their term is limited to a specified number of

36

From the low degree of public-ness of legal research stems a pecuniary advantage, which could not be realized by doing research in advance.

37

It may not always be easy to verify this observation, as courts more often than not do not cite their sources. Knowledge of the relevant legal literature will, however, make verification possible.

38

Concerning the American situation, it has been pointed out to me that not only legal scholars but scholars in any discipline relating to the specific problem posed before the court will find themselves in a situation similar to the one described for the schholarly community of lawyers in view of my German experience. This will be of some importance if the analysis is applied to the American scene.

39

Productivity is not easily measured; it should be a quantative measure (quantity to be given by number of appeals) as well as a qualitative measure (quality being seen in terms of the degree of adequateness of the constitutional ruling with respect ot the specific situation under consideration). The adequateness is, of course, highly debatable, involving political values and interests. Furthermore, even the number of problems (cases considered) is not externally given, but is dependent upon the expected adequacy of the court's decisions.

40

This is a more or less accurate generalized description of the German institutional framework. There are, however, variations as to the precise constitutional arrangements. Judges may be appointed by the chief executive only. Therefore, the representation of different parties will occur over time (provided there are varia tions in the relative strength of the various parties big enough to secure changes in the political executive as well) and will not necessarily reflect the actual strength of various groups in any given period. 
years, they will return to similar positions after having served their term or they may retire as well. From this, two more observations follow.

Supposition 9 (judicial dependency). Judges in the constitutional court, by virtue of their being appointed by government, will be ideologically attached to the appointing administration's political position (This follows from rational government's appointment decisions).

Supposition 10 (judicial power constraint). The possibility of the constitutional court's power being curbed by parliament amending the constitutional court's statue will limit judicial discretion.

If, in general, judges will be inclined to favor (present and former) executives' positions, the court in its main reasoning will - on the other hand - follow the arguments presented to it by the conflicting parties according to the adversary system adopted in Western legal culture. The court adopts all legal opinions presented before it and forms a coherent opinion out of the set of facts offered. This may be referred to as Supposition 11 (reconciliation). The constitutional court will try to reconcile all legal arguments advanced, and thus form a coherent constitutional interpretation.

Therefore, the completeness of the array of possible constitutional interpretations is of strategic importance for the achievement of a 'balanced' interpretation.

In sum, the court will generally try to do both things: endorse the government's position and try to harmonize the conflicting arguments presented as well.

The scholarly community of law professors is almost exclusively affiliated with law schools and universities; it is assumed here that the universities do not exert specific pressure on individual researchers to favor specific contentional results. This may not, of course, seem to be entirely plausible. The argument holds, however, in terms of this 'ideal' situation, as the final result is not dependant on assumptions which run counter to someone's professional ethics. If, however, it is postulated that there exists political and social pressure as to the results of individual legal research, competition between universities of different background and political ideals may be assumed to generate a wide array of alternative possible interpretations. Principle 12 (variety of legal opinion).

\subsection{Interaction}

Assume that the constitutional norm in question has up to now not been the subject of intensive legal research. It is possible to imagine a wide range of interpretation within which any lawyer may form himself an a priori opinion (before undertaking further research). The distribution of a priori opinions may, for example, be normal between two extreme points I and II; I denotes the position of the 'extreme' administration, and II denotes the interpretation most favoring the owners' interests.

The process of the interpretation of the constitution, which eventually decides which policy is to be carried out, will subsequently be described and explained by a sequence of three suppositions. 
The interested parties will sponsor university research. According to their specific interests, the parties select their researchers in view of the a priori opinions they may have expressed. From the point of view of the researchers, further work in this field will confirm his a priori opinion. ${ }^{41}$ If, in this situation, the court has to decide the conflict, it will, according to Suppositions (9)-(11), reconcile all arguments presented, favor the present administration's view so far as Supposition (10) suggests, and, moreover, express a certain bias toward the appointer-government's interpretation (9). Consider, however, the long-range impact of an externally induced process of research, undeterminated by the constitutional court's decision.

Initially, any researcher will publish his opinion in scholarly journals. Thus, a lawyer unspecialized in the field will become aware of problems concerning the interpretation of this norm.

$\underline{\text { Supposition } 13}$ (legal consciousness). The ratio of lawyers holding (unconsciously) a priori opinions to those conscious of the problem of interpretation, but as yet undecided, is negatively related to the quantity of research published. The more that is published, the more lawyers will become aware of intrinsic problems of interpretation.

Teaching will result in a further proliferation of the interpretation arrived at. The students of today will be the judges, officials, lawyers, and law professors of tomorrow. Published results will be read and to a certain degree appreciated and shared. Thus, not only will there be lawyers aware of possible problems of interpretation (problem-conscious), but also more and more members of the profession will hold specific a posteriori opinions, these opinions being those which lawyers have either learned or read and appreciated.

Supposition 14 (confirmation). The ratio $\left(\mathrm{R}_{\mathrm{d}}^{\mathrm{c}}\right)$ of those lawyers conscious of a certain legal problem to those holding a posteriori opinions is a negative function of time.

If the induced research had been sponsored equally over all possible a priori opinions according to their initial distribution, although legal knowledge would have certainly been deepened, the outcome would have only confirmed the a priori distribution. If, however, the research is sponsored in an unbalanced way, a shift in the legal consensus of opinion will take place. Consider a situation where the initiation of research is unbalanced, as in Table 1. Government may face five different interest groups of owners (different industries) and any party may sponsor the research of two law professors; ${ }^{42}$ in turn, any law

41

This assumption is by no means necessary, but it facilitates the analysis. We need only postulate a certain probability of the researchers' confirming their a priori opinions. There is no reason why these probabilities should differ for right wing or left wing researchers. Therefore, the final outcome does not change with this simplifying assumption.

42

These figures, although fictionally chosen in this example, are nevertheless realistic. In the case of 
professor may teach ten law students annually. This results in a distribution of a posteriori opinions among practitioners (officials, lawyers, judges), which will become relevant when these persons have to apply the norm in question, as shown in Table 1.

the socialization in Hesse (referred to in N.8), the owner-induced research at least outnumbered research induced by the government of Hess five times.

For details, see Backhaus, 'Politikwissenschaftliche Analyse interpretatorischer Veränderungsnormen". Politische Vierteljahresschrift 17, 1976, p. 54. 
Table 1.

\begin{tabular}{lrrrrrrrr}
\hline Years & 1 & 2 & 3 & 4 & 5 & 6 & 7 & 21 \\
\hline $\mathrm{I}$ & 2 & 20 & 40 & 60 & 80 & 100 & 120 & 400 \\
$\mathrm{II}$ & 10 & 100 & 200 & 300 & 400 & 500 & 600 & 2,400 \\
$\mathrm{R}_{\mathrm{d}}^{\mathrm{c}}$ & 833 & 83 & 41 & 31 & 21 & 16 & 14 & 4
\end{tabular}

Note: * Ratio of problem-conscious lawyers to determined lawyers.

However, the total membership of the guild (practitioners as well as university law professors) may be held more or less constant and limited. Assume that the guild is held constant at about 10,000 graduates from law schools and universities. Then, the ratio of problem-conscious to determined lawyers $\left(\mathbf{R}_{\mathrm{d}}^{\mathrm{c}}\right)$ will rapidly decline as shown in the third row. Of fourteen lawyers, chosen by chance, in our example after seven years, one will have a determined opinion. This will more often than not be the opinion of that party which has induced the most research; more specifically, the balance of induced research reproduces itself constantly and in unbiased fashion over time. If, for example, after twenty-one years the constitutional court has to decide upon the problem, with a jury of eight, two will have a determined opinion. In our example, of these two none will have opinion I. (The probability that opinion I will be represented in the jury, 11/36; the probability that opinion II will be represented, 35/36; the probability that only opinion II will be represented 25/36; however, the probability that only opinion I will be represented is $1 / 36$, that is, approximately 3 percent. Thus, it is certain by accepted statistical standards that opinion I will not be represented in the jury singularly.) If the remaining judges do not simply follow the majority's opinion (which they usually do) but follow instead the presented opinions according to their frequency, (I) will surely be defeated, and (II) certainly will be established.

Supposition 15 (biased interpretation). Given an unbalanced research impulse, the deviation from the median interpretation of a posteriori opinions commonly held is a positive function of time. If, however, the constitutional court had decided earlier, the result might have been different. Consider the constitutional court deciding in period 1 with all researchers acting as amici curiae (counsils to the court). Then, according to Supposition 11, the court will try to reconcile all presented arguments. If the court gives each argument equal weight, the decision will finally result in a position one-third to the right of the median of balanced interpretation. The exact position will further be determined by the influences indicated in Suppositions (9)-(10).

\subsection{Propositions}

From these assumptions (suppositions, premises, and principles),several propositions can be deduced. We may distinguish three different situations: (1) The process of interpretation of the constitution begins before the extreme administration comes to power; (2) the process begins at the same time as (or shortly after) it assumes power; (3) the process begins when the extreme administration is firmly established. 
1. The first situation is of great practical interest. As only one party (the owners) acts, ${ }^{43}$ the consensus of opinion is influenced asymmetrically and drifts to an extreme position (13)-(15). The next generation of judges, officials, lawyers, and law professors will be unaware of any legal opinion differing from the extreme position reached. It should be noted that this result occurs without the slightest participation of the constitutional court. ${ }^{44}$ The resulting interpretation in our example will be a high compensation requisite and/or the limitation of the applicability of the norm. Government, facing its budget constraint (3), will be barred from applying its once unquestioned constitutional prerogative. The protection of property and ownership will be complete. ${ }^{45}$

From this, Proposition I follows:

An interested party can, in the absence of any counter activity, influence the process of the interpretation of the constitution in the long run so that the authentic interpretation of the constitution drifts to the desired extreme. To achieve this, there is no need for any explicit statement from the constitutional court.

Although this first situation is the simplest in terms of the model presented here, Proposition 1 describes most cases of dramatic changes in the interpretation of the constitution which occur. At the same time, the model explains why those changes are not noticed. ${ }^{46}$

43

The administration in power will not show the slightest interest in influencing the process. But an extreme party, hoping to gain power some day, might. It could influence the process as well, a case excluded from analysis in this context despite its obvious importance. Extreme parties, moreover, often have a higher share of partisans in universities - even in law departments - than in the rest of the population.

44

Extreme interpretations of the constitution must not therefore be necessarily attributed to an 'imperial judiciary', as Glazer (1975) seems to imply.

45

At least individually and for that moment. The institution (public good aspect) of individual ownership, however, may well have been endangered at the same time. It is quite improbable that the interpretation of the constitution can prevent a majority quest for expropriation in the long run; it might on the contrary lead to a constitutional crisis and, eventually, to a revolutionary change in the constitution.

46

It need not be explained here whether potentially interested parties or groups enter PIC and why for some time they may not pay attention to the ongoing process of the interpretation of the constitution and its possible effects. Explaining this would require a different model. (A preliminary explanation might be a temporary lack of interest for the policy alternative concerned by its traditional or potential advocates.) Stress is only to be laid on the very possibility of an interpretational change unnoticed by the public, which public would be required to approve changes in the constitution. 
2. The process may be initiated by either party: the extreme administration, only recently inaugurated, will face a deficit of legitimacy (2); so it will be risk averse in court. Bureaucracy, still ideologically committed to the earlier executive's political goals (4), will act reluctantly and uneasily. This will prevent the implementation of optimal strategies of litigation. The legal advice produced by the bureaus, and legal activity undertaken on behalf of the government, will still be inspired by the former administration's ideology. Supposedly extreme (in the same sense as the administration) legal scholars (12) will not be consulted by bureaucracy, or only consulted haphazardly; hence, a limited range of possible arguments will be presented in court - consequence (11). In particular the government will be denied its extreme wing of argumentation which will not be presented in court and therefore need not be reconciled with the remaining argumentation presented. At the same time, the executive cannot profit from the appointment of judges committed to the governing party. The extreme administration has to face its predecessor's judicial appointees, who are hostile to the new governing party. The legitimacy deficit (2) will severely limit the executive's ability to threaten to curb the constitutional court's power (10).

Owners, on the other hand, will present the whole range of possible arguments, $(1,12)$, including their extreme wing of argumentation. The more they fear the implementation of the extreme administration's policy (of expropriation), the more they will invest in political and forensic lobbying (5). The resulting verdict of the constitutional court will be to the right of the median position of possible interpretations (11),(15). The executive will have to abstain from the implementation of the intended policy in order to avoid a defeat in court, ${ }^{47}$ a defeat which it cannot afford at that time (2) but which seems to be very likely. This gives us Proposition II:

An extreme administration, recently inaugurated, will in the presence of active and powerful adversaries in constitutional litigation be only partly able to profit from its constitutional prerogative.

The outcome, however, will be more favorable to the executive if it succeeds in prolonging constitutional litigation until new judges have been appointed. Gradually, it should also be possible to inspire bureaucracy with the new ideology as well, so as to secure effective collaboration. But this situation resembles more closely the case analyzed below.

3. The extreme administration may seemingly remain inactive with respect to the implementation of its extreme policy for some time after assuming power. After overcoming its initial legitimacy deficit (2), inspiring bureaucracy with the new ideology (4) and thus securing effective

The probable escape from this dilemma will be sought in regulating the industries concerned and settling out of court. This outcome if Pareto-optimal for the parties involved. The excecutive avoids open defeat in court, implementating, however, at least an attenuated version of its program; the owners do not suffer losses but gain guaranteed and protected profits; part of the government's bureaucracy will finally gain power. 
cooperation; and, furthermore, appointing judges committed to its party and policy (9), it will be able to effectively curb judicial discretion, thus preventing adverse verdicts (10). If the executive now initiates the constitutional battle, the outcome will be balanced - assuming effective litigation on both parts - or even biased in favor of the government, which can now secure the "government's bonus" (9),(10). For this strategy to be effective, a limited period of inactivity on the owner's side is a prerequisite. An extremely effective policy of appeasement of owner's suspicions must accordingly have taken place. This corresponds to a phase of investment in legitimacy (2).

If the administration waits for as long as almost one term, however, the alarmed owners, in view of the impending successful implementation of the government's policy, will invest (5) not only in the constitutional but also in the political battle (before elections). This might be dangerous for government, damaging its reelection probabilities. ${ }^{48}$ It brings us to Proposition III:

An extreme administration being firmly established can effectively pursue extreme policies by taking advantage of constitutional prerogatives and, if the constitutional adversaries after its inauguration abstain from strategically influencing the process of the interpretation of the constitution and constitutional litigation for a certain period, it can secure an authentic interpretation of the constitution very much biased in its own favor, stretching the wording of the constitution to its outer limits.

\subsection{Concluding remarks}

The process of the interpretation of the constitution has been shown to be politically neutral in the sense that there is no inherent political bias with respect to differing political viewpoints. The process, on the other hand, stabilizes whatever diverse impulses it receives. There is no evidence of a (second) supposition of reconciliation of political viewpoints (according to the supposition of reconciliation of legal interpretations) underlying the process, so unbalanced impulses (issued from whatever political direction) will be worked out. The imbalance will be stabilized as a new balance; imbalances are stabilized as such, not attenuated nor counterbalanced by the process itself. Any counterbalance must come as the consequence of a new external impulse.

SIC is nevertheless no barrier to political and social change. There will be difficulties arising out of SIC concerning short-run policies extreme enough to induce constitutional controversy. SIC can, however, be employed as a device for the long-run implementation of far-reaching structural change. SIC is a delicate political instrument; it will only be useful as an operational device for the implementation of the policy as a specific political party or interest group if there is no opposing influence exerted on SIC by another party or group. Parties or groups unable to secure enough votes in the political process should try to gain access to SIC in order to pursue their political ends efficiently. For those parties or groups insufficiently important to attract much public attention (and opposed strategies of extensive litigation),

48

This problem is excluded here. See N. 33. 
SIC is a useful device. Under a shield of public ignorance, ${ }^{49}$ these groups can gain power and access to political decisions, thus exerting an influence much in excess of their importance and weight in a democratic process of public decision-making.

\section{A summary and outline of further research}

Perhaps, the 1990's will be the decade of constitution writing. With many European States gaining their independence or reshaping their contours, new constitutions will be drawn up. Recent advances in the economic analysis of law can help to make this difficult task more feasible. This essay starts by giving an introduction into the economic analysis of constitutional law. Part I contains an analysis of constitutional guarantees of basic (individual) rights and procedures, illustrated with three constitutions, the American constitution of 1789 as amended in 1792, the German Basic Law of 1949 and the Dutch Basic Law of 1983. Although constitutions are meant to be permanent, they continuously change without amendment. Part II offers an analysis of constitutional change without amendment. Whoever wants to draft a constitution needs to know how the basic guarantees work, how procedural rules interconnect basic guarantees and decision takers, and what chances there are that the meaning of a constitutional provision can be turned upside down. Economic analysis of constitutions speaks to these three problems.

For a related analysis, see Bartlett. Economic Foundations of Political Power. New York, 1973. 


\section{References}

Backhaus, Jürgen. "Politikwissenschaftliche Analyse interpretatorischer Veränderungsnormen". Politische Vierteljahresschrift 17, 1976, pp. 520-576.

Backhaus, Jürgen, Öffentliche Unternehmen, Frankfurt, 1980 (2).

Backhaus, Jürgen, Mitbestimmung im Unternehmen. Göttingen: Vandenhoeck \& Ruprecht, 1987 (part B).

Backhaus, Jürgen, "Handleiding voor een economische analyse van een juridisch probleem", Ch. 12. In: R.W. Holzhauer, R. Teijl et. al. Inleiding Rechtseconomie, Arnhem: Gouda Quint, 1989, pp. 303-311.

Bartlett, Randall. Economic Foundations of Political Power. New York, 1973.

Baumol, William J. Welfare Economics and the Theory of the State. London, 1965.

Berge, ten, J.B.J.M., Rechtseconomie en Staatsrecht - Bestuursrecht". In: E.H. Hondius, J.J. Schippers, J.J. Siegers (eds.), Rechtseconomie en Recht, Zwolle: W.E.J. Tjeenk Willink, 1990.

Buchanan, James M. The Limits of Liberty. Chicago, 1975.

Buchanan, James M. and Tullock, Gordon. The Calculus of Consent. Ann Arbor, 1962.

Calabresi, Guido, The Costs of Accidents: A legal and Economic Analysis. New Haven: Yale University Press, 1970.

Downs, Anthony. Inside Bureaucracy. Boston, 1967.

Friedman, Milton. "The Methodology of Positive Economics". Essays in Positive Economics. Chicago, 1953.

Gäfgen, Gérard. Zur Ökonomik der Ideologiebildung". Wirtschaftsordnung und Staatsverfassung. Festschrift für Franz Böhm. Edited by Heinz Sauermann and Ernst-Joachim Mestmäcker. Tübingen, 1975.

Glazer, Nathan. "Toward an Imperial Judiciary". Public Interest 411975.

Goldberg, Victor. "On Positive Theories of Redistribution". Unpublished manuscript, Center for Study of Public Choice, Blackburg, Virginia, 1976.

Hayek, Friedrich A., Law, Legislation, and Liberty. Vol. 1-3. Chicago: University of Chicago Press, 1973, 1976, 1979.

Hirschman, Albert. O., Edit, Voice, and Loyalty: Purposes to Decline in Firms, Organizations, and States. Cambridge: Harvard University Press, 1970.

Kirchheimer, Otto. "Die Grenzen der Enteignung". Berlin, Leipzig, 1930.

Meier-Abich, Klaus M. \& Bertram Schefold, Wie möchten Wir in Zukunft Leben? Der "Harte" und der "Sanfte" Weg. München: Beck, 1981, pp.

Möschel, Wernhard, "Corporation Policy From an Ordo Point of View". Ch. 7. In: Alan Peacock and Hans Willgerodt (eds.), German Neo-Liberals and the Social Market Economy. New York: St. Martin's, 1989, pp. 142-178.

Posner, Richard A., "The Law and Economics Movement" (Richard T. Ely Lectur). American Economic Review papers and proceedings, 47.2, 1987, pp. 1-11.

Rae, Duncan, W. "Decision Rules and Individual Values in Constitutional Choice". American Political Science Review 40, 1969.

Rawls, John. A Theory of Justice. Oxford: Oxford University Press, 1971.

Schefold, Bertram, "Die beiden Wege". In: Meier-Abich/Schefold 1981, pp. 133-162. 
Spiethoff, Arthur, "Die Allgemeine Volkswirtschaftslehre als Geschichtliche Theorie: Die Wirtschaftsstile". In: Arthur Spiethoff (ed.), Festgabe für Werner Sombart zur Siebenzigsten Wiederkehr Seines Geburtstages. Neunzehnter Jänner 1933. München: Duncker \& Humblot 1933, pp. 51-84.

Williamson, Oliver E., "The Modern Corporation: Origins, Evolution, Attributes". Journal of Economic Literature XIX.4, 1981, pp. 1537-1568.

Yeager, Leland B., "Deregulation and Monetary Reform". American Economic Review, Papers and Proceedings, 75.2, 1985, pp. 103-107. 


\section{Appendix I}

\section{$\underline{\text { A. Bill of Rights }}$}

\section{Amendment I}

Congress shall make no law respecting an establishment of religion, or prohibiting the free exercise thereof; or abridging the freedom of speech, or of the press; or the right of the people peaceably to assemble, and to petition the Government for a redress of grievances.

\section{Amendment II}

A well regulated Militia, being necessary to the security of a free State, the right of the people to keep and bear Arms, shall not be infringed.

\section{Amendment III}

No Soldier shall, in time of peace be quartered in any house, without the consent of the Owner, nor in time of war, but in a manner to be prescribed by law.

\section{Amendment IV}

The right of the people to be secure in their persons, houses, papers, and effects, against unreasonable searches and seizures, shall not be violated, and no Warrants shall issue, but upon probable cause, supported by Oath or affirmation, and particularly describing the place to be searched, and the persons or things to be seized.

\section{Amendmet V}

No person shall be held to answer for a capital, or otherwise infamous crime, unless on a presentment or indictment of a Grand Jury, except in cases arising in the land or naval forces, or in the Militia, when in actual service in time of War or public danger; nor shall any person be subject for the same offence to be twice put in jeopardy of life or limb, nor shall be compelled in any criminal case to be a witness against himself, nor be deprived of life, liberty, or property, without due process of law; nor shall private property be taken for public use, without just compensation.

\section{Amendment VI}

In all criminal prosecutions, the accused shall enjoy the right to a speedy and public trial, by an impartial jury of the State and district wherein the crime shall have been committed, which district shall have been previously ascertained by law, and to be informed of the nature and cause of the accusation; to be confronted with the witnesses against him; to have compulsory process for obtaining Witnesses in his favor, and to have the Assistance of Counsel for his defence.

\section{Amendment VII}

In Suits at common law, where the value in controversy shall exceed twenty dollars, the right of trial by jury shall be preserved, and no fact tried by a jury, shall be otherwise re-examined in any Court of the United States, than according to the rules of the common law. 
Amendment VIII

Excessive bail shall not be required, nor excessive fines imposed, nor cruel and unusual punishments inflicted.

Amendment IX

The enumeration in the Constitution, of certain rights, shall not be construed to deny or disparage others retained by the people.

Amendment X

The powers not delegated to the United States by the Constitution, nor prohibited by it to the States, are reserved to the States respectively, or to the people.

B. Basic Law of 1949

Artikel 2

1. Jeder hat das Recht auf die freie Entfaltung seiner Persönlichkeit, soweit er nicht die Rechte anderer verletzt und nicht gegen die verfassungsmässige Ordnung oder das Sittengesetz verstösst.

2. Jeder hat das Recht auf Leben und körperliche Unversehrheit. Die Freiheit der Person ist unverletzlich. In diese Rechte darf nur auf Grund eines Gesetzes eingegriffen werden.

Artikel 9

1. Alle Deutschen haben das Recht, Vereine und Gesellschaften zu bilden.

2. Vereinigungen, deren Zwecke oder deren Tätigkeit den Strafgesetzen zuwiderlaufen oder die sich gegen die verfassungsmässige Ordnung oder gegen den Gedanken der Völkerverständigung richten, sind verboten.

3. Das Recht, zur Wahrung und Förderung der Arbeits- und Wirtschaftsbedingungen Vereinigungen zu bilden, ist für jedermann und für alle Berufe gewährleistet. Abreden, die dieses Recht einschränken oder zu behindern suchen, sind nichtig, hierauf gerichtete Massnahmen sind rechtswidrig. Massnahmen nach den Artikeln 12a, 35 Abs. 2 und 3, Artikel 87 a Abs. 4 und Artikel 91 dürfen sich nicht gegen Arbeitskämpfe richten, die zur Wahrung und Förderung der Arbeits- und Wirtschaftsbedingungen von Vereinigungen im Sinne des Satzes 1 geführt werden.

Artikel 12

1. Alle Deutschen haben das Recht, Beruf, Arbeitsplatz und Ausbildungsstätte frei zu wählen. Die Berufsausübung kann durch Gesetz oder auf Grund eines Gesetzes geregelt werden.

2. Niemand darf zu einer bestimmten Arbeit gezwungen werden, ausser im Rahmen einer herkömmlichen allgemeinen, für alle gleichen öffentlichen Dienstleistungspflicht.

3. Zwangsarbeit ist nur bei einer gerichtlich angeordneten Freiheitsentziehung zulässig.

Artikel 14

1. Das Eigentum und das Erbrecht werden gewährleistet. Inhalt und Schranken werden durch die Gesetze bestimmt. 
2. Eigentum verpflichtet. Sein Gebrauch soll zugleich dem Wohle der Allgemeinheit dienen.

3. Eine Enteignung ist nur zum Wohle der Allgemeinheit zulässig. Sie darf nur durch Gesetz oder auf Grund eines Gesetzes erfolgen, das Art und Ausmass der Entschädigung regelt. Die Entschädigung ist unter gerechter Abwägung der Interessen der Allgemeinheit und der Beteiligten zu bestimmen. Wegen der Höhe der Entschädigung steht im Streitfalle der Rechtsweg vor den ordentlichen Gerichten offen.

Artikel 15

Grund und Boden, Naturschätze und Produktionsmittel können zum Zwecke der Vergesellschaftung durch ein Gesetz, das Art und Ausmass der Entschädigung regelt, in Gemeineigentum oder in andere Formen der Gemeinwirtschaft überführt werden. Für die Entschädigung gilt Artikel 14 Absatz 3 Satz 3 und 4 entsprechend.

Artikel 20

1. Die Bundesrepublik Deutschland ist ein demokratischer und sozialer Bundesstaat.

2. Alle Staatsgewalt geht vom Volke aus. Sie wird vom Volke in Wahlen und Abstimmungen und durch besondere Organe der Gesetzgebung, der vollziehenden Gewalt und der Rechtsprechung ausgeübt.

3. Die Gesetzgebung ist an die verfassungsmässige Ordnung, die vollziehende Gewalt und die Rechtsprechung sind an Gesetz und Recht gebunden.

4. Gegen jeden, der es unternimmt, diese Ordnung zu beseitigen, haben alle Deutschen das Recht zum Widerstand, wenn andere Abhilfe nicht möglich ist.

Artikel 21

1. Die Parteien wirken bei der politischen Willensbildung des Volkes mit. Ihre Gründung ist frei. Ihre innere Ordnung muss demokratischen Grundsätzen entsprechen. Sie müssen über die Herkunft ihrer Mittel öffentlich Rechenschaft geben.

2. Parteien, die nach ihren Zielen oder nach dem Verhalten ihrer Anhänger darauf ausgehen, die freiheitliche demokratische Grundordnung zu beeinträchtigen oder zu beseitigen oder den Bestand der Bundesrepublik Deutschland zu gefährden, sind verfassungswidrig. Über die Frage der Verfassungswidrigkeit entscheidet das Bundesverfassungsgericht.

3. Das Nähere regeln Bundesgesetze.

Artikel 23

Diese Grundgesetz gilt zunächst im Gebiete der Länder Baden, Bayern, Bremen, Groß-Berlin, Hamburg, Hessen, Niedersachsen, Nordrhein-Westfalen, Rheinland-Pfalz, Schleswig-Holstein, Württemberg-Baden und Württemberg-Hohenzollern (Vgl. Anmerkung zur Präambel). In anderen Teilen Deutschlands ist es nach deren Beitritt in Kraft zu setzen. 


\section{Grondwet}

Artikel 1

Allen die zich in Nederland bevinden, worden in gelijke gevallen gelijk behandeld. Discriminatie wegens godsdienst, levensovertuiging, politieke gezindheid, ras, geslacht of op welke grond dan ook, is niet toegestaan.

\section{Artikel 2}

1. De wet regelt wie Nederlander is.

2. De wet regelt de toelating en de uitzetting van vreemdelingen.

3. Uitlevering kan slechts geschieden krachtens verdrag. Verdere voorschriften omtrent uitlevering worden bij de wet gegeven.

4. Ieder heeft het recht het land te verlaten, behoudens in de gevallen, bij de wet bepaald.

Artikel 4

Iedere Nederlander heeft gelijkelijk recht de leden van algemeen vertegenwoordigende organen te verkiezen alsmede tot lid van deze organen te worden verkozen, behoudens bij de wet gestelde beperkingen en uitzonderingen.

\section{Artikel 5}

Ieder heeft het recht verzoeken schriftelijk bij het bevoegd gezag in te dienen.

Artikel 6

1. Ieder heeft het recht zijn godsdient of levensovertuiging, individueel of in gemeenschap met anderen, vrij te belijden, behoudens ieders verantwoordelijkheid volgens de wet.

2. De wet kan ter zake van de uitoefening van dit recht buiten gebouwen en besloten plaatsen regels stellen ter bescherming van de gezondheid, in het belang van het verkeer en ter bestrijding of voorkoming van wanordelijkheden.

\section{Artikel 7}

1. Niemand heeft voorafgaand verlof nodig om door de drukpers gedachten of gevoelens te openbaren, behoudens ieders verantwoordelijkheid volgens de wet.

2. De wet stelt regels omtrent radio en televisie. Er is geen voorafgaand toezicht op de inhoud van een radio- of televisieuitzending.

3. Voor het openbaren van gedachten of gevoelens door andere dan in de voorgaande leden genoemde middelen heeft niemand voorafgaand verlof nodig wegens de inhoud daarvan, behoudens ieders verantwoordelijkheid volgens de wet. De wet kan het geven van vertoningen toegankelijk voor personen jonger dan zestien jaar regelen ter bescherming van de goede zeden.

4. De voorgaande leden zijn niet van toepassing op het maken van handelsreclame.

\section{Artikel 8}


Het recht tot vereniging wordt erkend. Bij de wet kan dit recht worden beperkt in het belang van de openbare orde.

\section{Artikel 9}

1. Het recht tot vergadering en betoging wordt erkend, behoudens ieders verantwoordelijkheid volgens de wet.

2. De wet kan regels stellen ter bescherming van de gezondheid, in het belang van het verkeer en ter bestrijding of voorkoming van wanordelijkheden.

Artikel 10

1. Ieder heeft, behoudens bij of krachtens de wet te stellen beperkingen, recht op eerbiediging van zijn persoonlijke levenssfeer.

2. De wet stelt regels ter bescherming van de persoonlijke levenssfeer in verband met het vastleggen en verstrekken van persoonsgegevens.

3. De wet stelt regels inzake de aanspraken van personen op kennisneming van over hen vastgelegde gegevens en van het gebruik dat daarvan wordt gemaakt, alsmede op verbetering van zodanige gegevens.

\section{Artikel 11}

Ieder heeft, behoudens bij of krachtens de wet te stellen beperkingen, recht op onaantastbaarheid van zijn lichaam.

\section{Artikel 12}

1. Het binnentreden in een woning tegen de wil van de bewoner is alleen geoorloofd in de gevallen bij of krachtens de wet bepaald, door hen die daartoe bij of krachtens de wet zijn aangewezen.

2. Voor het binnentreden overeenkomstig het voorgaande lid is voorafgaande legitimatie en mededeling van het doel van het binnentreden vereist. Aan de bewoner wordt een schriftelijk verslag van het binnentreden verstrekt.

\section{Artikel 13}

1. Het briefgeheim is onschendbaar, behalve, in de gevallen bij de wet bepaald, op last van de rechter.

2. Het telefoon- en telegraafgeheim is onschendbaar, behalve, in de gevallen bij de wet bepaald, door of met machtiging van hen die daartoe bij de wet zijn aangewezen.

Artikel 14

1. Onteigening kan alleen geschieden in het algemeen belang en tegen vooraf verzekerde schadeloosstelling, een en ander naar bij of krachtens de wet te stellen voorschriften.

2. De schadeloosstelling behoeft niet vooraf verzekerd te zijn, wanneer in geval van nood onverwijld onteigening geboden is. 
3. In de gevallen bij of krachtens de wet bepaald bestaat recht op schadeloosstelling of tegemoetkoming in de schade indien in het algemeen belang eigendom door het bevoegd gezag wordt vernietigd of onbruikbaar gemaakt of de uitoefening van het eigendomsrecht wordt beperkt.

Artikel 19

1. Bevordering van voldoende werkgelegenheid is voorwerp van zorg der overheid.

2. De wet stelt regels omtrent de rechtspositie van hen die arbeid verrichten en omtrent hun bescherming daarbij, alsmede omtrent medezeggenschap.

3. Het recht van iedere Nederlander op vrije keuze van arbeid wordt erkend, behoudens de beperkingen bij of krachtens de wet gesteld.

Artikel 20

1. De bestaanszekerheid der bevolking en spreiding van welvaart zijn voorwerp van zorg der overheid.

2. De wet stelt regels omtrent de aanspraken op sociale zekerheid.

3. Nederlanders hier te lande, die niet in het bestaan kunnen voorzien, hebben een bij de wet te regelen recht op bijstand van overheidswege.

\section{Artikel 21}

De zorg van de overheid is gericht op de bewoonbaarheid van het land en de bescherming en verbetering van het leefmilieu.

Artikel 22

1. De overheid treft maatregelen ter bevordering van de volksgezondheid.

2. Bevordering van voldoende woongelegenheid is voorwerp van zorg der overheid.

3. Zij schept voorwaarden voor maatschappelijke en culturele ontplooiing en voor vrijetijdsbesteding.

Artikel 23

1. Het onderwijs is een voorwerp van de aanhoudende zorg der regering.

2. Het geven van onderwijs is vrij, behoudens het toezicht van de overheid en, voor wat bij de wet aangewezen vormen van onderwijs betreft, het onderzoek naar de bekwaamheid en de zedelijkheid van hen die onderwijs geven, een en ander bij de wet te regelen.

3. Het openbaar onderwijs wordt, met eerbiediging van ieders godsdienst of levensovertuiging, bij de wet geregeld.

4. In elke gemeente wordt van overheidswege voldoend openbaar algemeen vormend lager onderwijs gegeven in een genoegzaam aantal scholen. Volgens bij de wet te stellen regels kan afwijking van deze bepaling worden toegelaten, mits tot het ontvangen van zodanig onderwijs gelegenheid wordt gegeven.

5. De eisen van deugdelijkheid, aan het geheel of ten dele uit de openbare kas te bekostigen onderwijs te stellen, worden bij de wet geregeld, met inachtneming, voor zover het bijzonder onderwijs betreft, van de vrijheid van richting. 
6. Deze eisen worden voor het algemeen vormend lager onderwijs zodanig geregeld, dat de deugdelijkheid van het geheel uit de openbare kas bekostigd bijzonder onderwijs en van het openbaar onderwijs even afdoende wordt gewaarborgd. Bij die regeling wordt met name de vrijheid van het bijzonder onderwijs betreffende de keuze der leermiddelen en de aanstelling der onderwijzers geërbiedigd.

7. Het bijzonder algemeen vormend lager onderwijs, dat aan de bij de wet te stellen voorwaarden voldoet, wordt naar dezelfde maatstaf als het openbaar onderwijs uit de openbare kas bekostigd. De wet stelt de voorwaarden vast, waarop voor het bijzonder algemeen vormend middelbaar en voorbereidend hoger onderwijs bijdragen uit de openbare kas worden verleend.

8. De regering doet jaarlijks van de staat van het onderwijs verslag aan de Staten-Generaal. 


\section{Appendix II}

Summary of the Argument in Post IV

In order to facilitate the analysis and critique of the model presented, a compilation of assumptions and postulates advanced in this paper is given:

Supposition 1: (strategic litigation)

Supposition 2: (legitimacy deficit)

Premise 3: $\quad$ (budget constraint)

Supposition 4: (ideological delay)

Supposition 5: (inverse investment behavior)

Principle 6: (non-interstedness)

Supposition 7: (external impulse)

Supposition 8: (source of interpretative ideas)

Supposition 9: (judicial dependency)

Supposition 10: (judicial power constraint)

Supposition 11: (reconciliation)

Principle 12: (variety of legal opinion)

Supposition 13: (legal consciousness)

Supposition 14: (confirmation)

Supposition 15: (biased interpretation)

Proposition I: An Interested party can, in the absence of any counteractivity, influence the process of the interpretation of the constitution in the long run so that the authentic interpretation of the constitution drifts to the desired extreme. To achieve this there is no need of any explicit statement from the constitutional court.

Proposition II: An extreme administration, recently inaugurated, will in the presence of active and powerful adversaries in constitutional litigation, be only partly able to profit from its constitutional prerogatives.

Proposition III: An extreme administration, being firmly established, can effectively pursue extreme policies by taking advantages of constitutional prerogatives and, if the constitutional adveraries after its inauguration abstain from strategically influencing the process of the interpretation of the constitution as well as from constitutional litigation for a certain period, it can secure an authentic interpretation of the constitution biased in its favor, stretching the wording of the constitution to its outer limits. 